Article

\title{
Barriers for the Sustainable Development of Entertainment Tourism in Macau
}

\author{
Jian Ming Luo ${ }^{1}$, Chi Fung Lam ${ }^{2}$ and Ben Haobin Ye ${ }^{3, *}$ \\ 1 Faculty of International Tourism and Management, City University of Macau, Macau, China; \\ kenny.luo@connect.polyu.hk \\ 2 Department of Finance, The Chinese University of Hong Kong, Hong Kong, China; kelvinlam@cuhk.edu.hk \\ 3 School of Tourism Management, South China Normal University, Guangzhou 510006, China \\ * Correspondence: ben_ye@m.scnu.edu.cn or damonyhb@hotmail.com
}

Received: 2 March 2019; Accepted: 28 March 2019; Published: 10 April 2019

check for updates

\begin{abstract}
Entertainment tourism is attracting attention from the industry and the academics. This study aimed to discover the barriers for the development of entertainment tourism in Macau from the industry's perspective. A qualitative research approach was used to collect data from the entertainment tourism industry. Results show that policies and regulations, economy, marketing, management, government attitude, expertise and manpower, facilities and attractions as well as infrastructure problems are the main barriers for the development of entertainment tourism. Implications and suggestions for entertainment tourism practitioners are provided.
\end{abstract}

Keywords: entertainment tourism; barriers; tourism development; Macau

\section{Introduction}

Entertainment tourism, which is defined as economic activities based on integrated services provided by the entertainment and tourism sectors, is a rising trend around the world [1]. Entertainment products come in many forms, such as talk shows, concerts, magic performance, gambling, and dance performance. Gambling, which is also an entertainment product, is a key determinant of economic growth in many countries [2]. Macau is a large gambling destination in the world in terms of revenue and is the only city in China that legalizes gambling [3]. Thus, gambling is an important revenue source of the Macau government [4]. However, Macau is challenged by nearby destinations, such as Singapore, Philippines, South Korea, and Taiwan [5].

Since Macau introduced competition among gambling companies in the last decade, Macau and the Chinese government have been trying to diversify the economy for sustainable development. The attempts became increasingly important after the financial crisis in 2008. Although Macau inherits many holidays, festivals, events, and activities from Chinese and Portuguese culture, and can easily develop many new attractions and markets, such attempts have not been successful. The growth rate of non-gaming revenue is considerably lower than the growth rate of gaming revenue [6]. Although the House of Dancing Water is a successful show, the revenue generated from the show is considerably less than the revenue generated from the gaming sector. In addition, this non-gaming sector investment is risky. For example, ZAia, a circus show operated by Cirque du Soleil and the first residential show in Asia, was shut down due to the lack of audience. Therefore, an insufficient number of investors are willing to invest in "Macau-see, Macau-do" business [6].

An extensive review of the literature shows that very few studies on the barriers of entertainment tourism from the supply-side perspective are available. The current study aimed to discover the barriers for the sustainable development of entertainment tourism in Macau using data obtained from suppliers in entertainment tourism. The findings also provide practical implications for Macau and 
other entertainment destinations to develop entertainment tourism. The article is structured as follows. The first section defines entertainment tourism. The second section describes the qualitative research methodology used in the study. The final section identifies the barriers for the sustainable development of entertainment tourism in Macau. A corresponding framework is also presented.

\section{Literature Review}

\subsection{Entertainment Tourism Development}

Over the last two decades, the entertainment and tourism services industry has undergone major transformations. On the one hand, international tourist arrivals grew steadily. There were roughly 25 million international tourist arrivals in 1951, and this number has increased to over 1.4 billion in 2018. Furthermore, roughly $10 \%$ of the jobs in the world come from the tourism sector and around $30 \%$ of international exports of services come from tourism [7]. On the other hand, the entertainment sector is an important part of international business. The revenue generated from the entertainment and media market globally was close to 1.9 trillion USD in 2017 and is forecasted to reach 2.4 trillion in 2022 [8].

The entertainment industry has been evolving along with the destination in the last decade [9]. Entertainment destinations are places where people travel to participate in entertainment activities [1]. A classic example is Branson in Missouri, the second most popular destination in the United States [10]. Other examples are concerts, musicals, music and medieval festivals, magic and street performance, circus, comedy, sport events, theater, dancing, clubbing, and theme park visits [11]. Las Vegas has diversified from gambling and became an entertainment destination many years ago. Live performances are now the attractions of Las Vegas. The original purpose of live performance was to encourage tourists or visitors to stay in hotels or casinos. Apart from live performances, hotels also provide theme park and virtual reality experiences [12]. Not all entertainment requires venues. For example, media, the Internet, and video games do not need any venue. Therefore, these activities cannot be classified into tourism. Tourism and entertainment are two markets that mutually reinforce each other. Tourism provides potential customers with entertainment, whereas entertainment encourages the development of tourism. The overlapping areas are regarded as entertainment tourism [1].

Entertainment tourism is attracting attention from the industry and the academics [1]. Entertainment tourism is gaining considerable attention because it can encourage people to travel [13]. Vogel [14] defines entertainment as things that can stimulate, encourage, and generate enjoyable distractions. In fact, entertainment can generate more than distractions. Entertainment includes popular performing arts, such as concerts, musicals, and magic dance performances [15]. According to $\mathrm{Xu}$ [16], entertainment activities aim to satisfy the needs of visitors and create memorable experiences. Entertainment is important to many gambling destinations. Gambling and entertainment are excellent complements in creating impressive images and products of gambling destinations [17]. This combination is applied in Singapore, the United States, Australia, and Europe to reposition or diversify the destination from gambling [2].

Entertainment becomes a major attraction not only to existing tourists, but also to new customers who enjoy non-gaming activities more than gaming activities. As resorts integrate more non-gaming activities and amenities, non-gaming revenues are expected to increase. Suh and West [18] found a positive relationship between the presence of entertainment shows and gaming volume during the hours close to the show time. The main justification of investing a large sum of money in non-gaming amenities is the expectation or hope of attracting people to visit casinos [19]. Live performances can not only generate revenue for the resorts, but also increase the resort attractiveness to the tourists and their likelihood to gamble after the shows [20]. Many hotels provide other entertainment activities, such as theme parks, virtual reality, etc. This creates a demand for short-term accommodation during those periods. 


\subsection{Barriers for Tourism Development}

The growth of tourism has been tremendous in the last few decades because many destinations have become increasingly aware of the ability of tourism to improve the economy and resolve many socio-cultural problems [21]. However, tourism affects the society not only positively but also negatively, especially the community and the environment. Therefore, the sustainability of tourism becomes an important topic for destinations that aim to use tourism to improve the economy. Formica and Uysal [22] derived the theory and empirical research of potential tourism development from several sources. Tourism development has many constraints. From the financial perspective, the constraints include limited access to financial markets and limited confidence of domestic and international investors. From the regulation perspective, the constraints include complicated taxation requirements and procedures. Other constraints include limited budgetary allocation, lack of integration, and limited tourism promotion [23]. In addition to these constraints, Sharma [24] argued that the most important barriers are limited information, lack of awareness, and insufficient funding. Furthermore, Kay et al. [25] discovered the interconnection among eight barriers, namely, physical access, personal access, cost, time and timing, product, personal interest and peer group, socialization and understanding, and information.

Some wine and medical tourism studies have examined the barriers for tourism development. From the perspective of wine tourism, Marzo-Navarro and Pedraja-Iglesias [26] found that cost, time, and distance to the destination do not affect the barrier for wine tourism development. In a different research study, both authors found that the personal barrier is the most important for participation in wine tourism activities, whereas the structural barrier is the second most important. From the perspective of medical tourism, Heung et al. [27] found that policies and regulations, government support, costs, capacity problems, and the healthcare needs of the local community are the main barriers for the development of medical tourism in Hong Kong. In addition, Rokni et al. [28] found that policy, government regulations, language, promotion, and the number of experts are the major barriers of medical tourism by using a barrier framework. Momeni et al. [29] identified the barriers for the development of medical tourism in Iran. The results showed that marketing, international issues, culture, transfer, brokerage, management, and policy problems were the main barriers for the development of medical tourism.

In regional tourism studies, on the one hand, Hsu and $\mathrm{Gu}$ [30] discovered three important factors of tourism development, namely, travel permit policy by mainland China, land shortage and labor force, and the Macau government's liberalization of gaming operations. On the other hand, Greenwood and Dwyer [31] found that a narrow industrial base, competing destinations, and community alienation were factors affecting tourism development in Macau. Macau has both public and private buses and shuttle systems. However, both systems are now saturated, which creates traffic jams and pollution. These problems become more severe as the number of casino shuttles keeps increasing [32]. Furthermore, Macauhub [33] reported that the diversity of market sources is caused by the limited amount of international flights to Macau.

The above-mentioned considerable number of literature studies show that different tourism sectors possess unique characteristics and thus unique barriers. Therefore, the tourism sector needs appropriate planning to develop tourism properly, respond to market demands in a timely manner, and integrate into the general development of the society [34]. Macau is a key gaming destination in the world $[1,3,4,30,31]$. Unfortunately, insufficient studies have focused on this area. Therefore, this study aims to identify the major barriers of entertainment tourism in Macau.

\section{Methods}

This study applied a qualitative research approach, which is defined as any research findings that are not discovered using statistical procedures or quantification [35]. This method is commonly applied to identify variables that will be examined quantitatively in follow-up studies or when quantitative measures cannot be described or explained appropriately. Considering that entertainment tourism is 
relatively new and thus requires further development, this exploratory study adopted a grounded theory approach [35].

A qualitative method along with semi-structured interview was used to conduct the research. Taking into consideration our research objectives, it was reasonable to use a purposive and convenience sampling approach, which is common in qualitative studies, to select research participants to understand barriers of entertainment tourism in Macau from the industry's perspective. Sixteen interviews from the sectors of gambling, spa, dance club, and entertainment production, which are representative of the entertainment sector in Macau [36], were selected through the researchers' personal networks in May 2018. Most of the interviewees were from the management level, such as managers, senior managers, and general managers. A semi-structured questionnaire with open-ended questions was constructed on the basis of the characteristics of entertainment tourism in Macau. The questionnaire was divided into two sections. The first section collected the demographic information of the interviewees, whereas the second section collected information about barriers for entertainment tourism development. All questions were available in Chinese and English for the convenience of the interviewees. These questions included (1) What is entertainment tourism? Does any entertainment-related program for tourists exist in your company? (2) What are the core elements of management in entertainment tourism? (3) What are the barriers for implementing the entertainment tourism program? The interviews were conducted in Chinese. Each interview lasted about an hour. The back-to-back technique was used to translate the transcript immediately after the interviews. The constant comparison technique, a method developed by Glaser and Strauss [37], was used to record, code, and analyze the data. To ensure the validity of the content and avoid any confusion, all interviews were listened to and transcribed immediately. All interviews were sent to the interviewees for verification and approval [38]. Semi-structured interviews allowed the researchers to collect different views of dissimilar affecting factors of entertainment tourism development from the supply side. After the interviews were recorded and transcribed, the corresponding information was input into NVivo 11.0 (QSR International Pty Ltd, Melbourne, Australia) for further analysis. Content analysis was used in this research. This method prevented the researchers from examining the information independently and minimized any influence from any "a priori" theory. Thus, the results can be open for further discussion [39]. Three researchers examined the transcripts independently and collaboratively to build a framework of categorization. Inter-coder reliability was reached with more than $90 \%$ consistency and discrepancies were resolved through discussions.

\section{Findings and Discussion}

\subsection{Characteristics of Interviewees}

This study used personal interviews to identify the barriers for entertainment tourism development in Macau. Sixteen interviews were collected from senior managers with sufficient work experience in entertainment tourism. Of the respondents, $38 \%$ were male. Most respondents had more than 10 years of experience. The proportion of general managers and senior managers was $25 \%$ and $31 \%$, respectively. Of the respondents, $63 \%$ were from the gambling industry, and the remaining respondents were from the non-gambling industry. This sample should be sufficient to represent the senior management team in the entertainment tourism industry. Table 1 shows the demographic information of the interviewees. 
Table 1. Demographic information of interviewees.

\begin{tabular}{ccccc}
\hline No. & Sex & Working Experience (Years) & Industry Sector & Position \\
\hline 1 & $\mathrm{~F}$ & 4 & Gambling & Manager \\
2 & $\mathrm{~F}$ & 10 & Gambling & Manager \\
3 & $\mathrm{M}$ & 15 & Gambling & Senior Manager \\
4 & $\mathrm{M}$ & 12 & Gambling & Manager \\
5 & $\mathrm{~F}$ & 7 & Gambling & Manager \\
6 & $\mathrm{~F}$ & 10 & Gambling & General Manager \\
7 & $\mathrm{M}$ & 12 & Gambling & Senior Manager \\
8 & $\mathrm{M}$ & 20 & Gambling & General Manager \\
9 & $\mathrm{~F}$ & 10 & Gambling & Senior Manager \\
10 & $\mathrm{M}$ & 7 & Gambling & Manager \\
11 & $\mathrm{~F}$ & 11 & Spa & Senior Manager \\
12 & $\mathrm{M}$ & 2 & Entertainment Production & Manager \\
13 & $\mathrm{~F}$ & 3 & Spa & General Manager \\
14 & $\mathrm{~F}$ & 10 & Theater & Senior Manager \\
15 & $\mathrm{~F}$ & 20 & Spa & General Manager \\
16 & $\mathrm{~F}$ & 10 & Dance Club & Manager \\
\hline
\end{tabular}

\subsection{Framework of the Study}

The themes and sub-themes of the barriers for entertainment tourism development were combined to develop a framework. Figure 1 indicates the barriers for the development of entertainment tourism in Macau. Economy, policies and regulations, government attitude, expertise and manpower, management, marketing, infrastructural factors, and facilities and tourist attractions are the main barriers for entertainment tourism development. The solid arrows represent the direct effects, whereas the dashed arrows represent the relationship between factors. Using policies and regulations as an illustration, policies and regulations directly affect the development of entertainment tourism. At the same time, this theme affects other themes, such as government attitudes, marketing, management, and expertise and manpower.

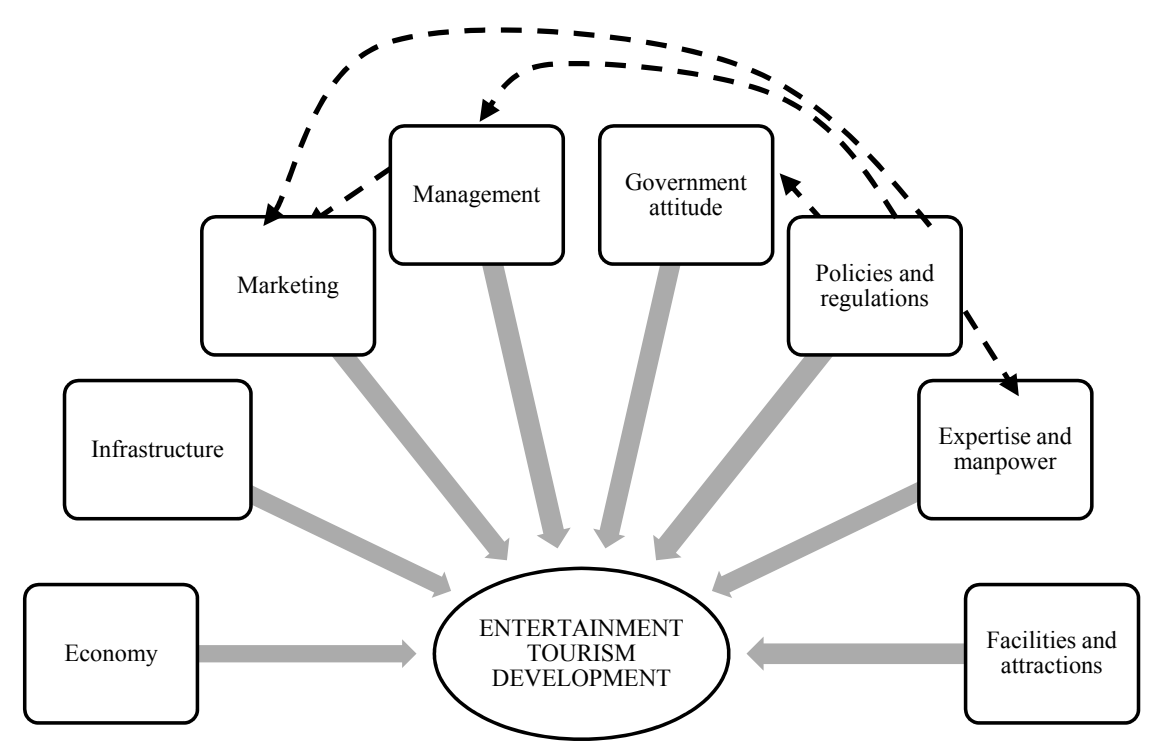

Figure 1. Framework of barriers for the development of entertainment tourism in Macau.

\subsection{Barriers for the Development of Entertainment Tourism}

Table 2 lists the main barriers for entertainment tourism development and their corresponding sub-themes. This study identifies similar barriers discovered by some of the previously mentioned literature studies $[23,27,29]$. This section investigates each factor accordingly. 
Table 2. Results of content analysis.

\begin{tabular}{|c|c|c|}
\hline Themes & Sub-Themes & Frequency Count \\
\hline Economy & Costs are high for entertainment in Macau & 5 \\
\hline \multirow{4}{*}{ Infrastructure } & Land scarcity & 5 \\
\hline & Traffic congestion & 2 \\
\hline & Lack of middle-scale hotels & 1 \\
\hline & Physical environment is unsuitable & 3 \\
\hline \multirow{3}{*}{ Marketing } & Lack of a local brand of entertainment & 2 \\
\hline & Poor communication of entertainment tourism with local & 3 \\
\hline & Promotion of old towns & 5 \\
\hline \multirow{3}{*}{ Management } & Lack of strategic planning & 3 \\
\hline & Lack of effective coordination among VIP junket operators & 4 \\
\hline & Lack of customer service in casinos for mass market & 2 \\
\hline \multirow{3}{*}{ Government attitude } & Support and promotion on entertainment development & 6 \\
\hline & New investment should be encouraged & 2 \\
\hline & Community innovation should be encouraged & 3 \\
\hline \multirow{3}{*}{ Policies and regulations } & Central government policy towards Macau & 7 \\
\hline & Restrictions on entertainment development & 9 \\
\hline & Complex procedures on entertainment license & 5 \\
\hline \multirow{2}{*}{ Expertise and manpower } & Limited number of experts & 6 \\
\hline & Lack of local specialists & 5 \\
\hline \multirow{3}{*}{ Facilities and attractions } & Lack of entertainment tourism destinations & 5 \\
\hline & Old town improvements & 3 \\
\hline & Lack of entertainment facilities & 8 \\
\hline
\end{tabular}

\subsubsection{Policies and Regulations}

Most interviewees said policies and regulations are important factors in entertainment tourism. This main theme has three sub-themes. First, central government policy towards Macau was believed to be a critical factor influencing entertainment tourism in Macau. One interviewee (Interviewee 7) mentioned that although Chinese residents can easily obtain a visa to visit Macau, the Chinese government imposes restrictions on the number of visits of Chinese residents. The travel permit regulation that limits the frequency of mainland Chinese visits to Macau poses a threat to the Macau tourism industry [30].

Second, at the industry level, restrictions on entertainment development were perceived to be an important political barrier. For example, the largest sector of entertainment tourism, which is gambling, is under stringent control. Because of gambling's particular nature in that it relates to many social problems, the industry is highly regulated by governmental entities. The number of licenses is usually limited to minimize an array of social costs [32]. Since Macau liberalized its gaming industry in 2001 and opened its borders to Chinese residents, it has developed into one of the world's largest gaming destinations. Macau's gaming industry deserves special attention since it is controlled by both local and central governments. The central government grants Macau the permission to be the only city in China to provide legalized gambling. Therefore, the central government's attitude can potentially affect the development of the gaming industry. Sheng [40] reported that the concession of gaming licenses is controlled by several parties. Upon the expiry of the concession of Sociedade de Turismo e Diversões de Macao (STDM) on 31 December 2001, the Macau Special Administrative Region (SAR) decided to grant three gaming concessions, in an effort to inject new dynamics into the gaming industry and to lay a strong foundation for further future development in gaming [41]. Third, complex procedures regarding entertainment licenses are another barrier under this theme. Although the Macau government has already constituted the legal framework regulating the entertainment industry in a relatively transparent and efficient way, the precise procedures to obtain a license for an entertainment company are complicated and time consuming. Therefore, this situation becomes a barrier, especially for young entrepreneurs, to start a business in Macau (Interviewee 16). 


\subsubsection{Economy (Costs)}

The second main theme is cost of production. The economy of Macau has been remarkable since its return to China in 1999. The average growth rate of GDP was 8.96\% per annum from 2002 to 2018, and the GDP per capita was over 50,000 USD in 2017. Thus, the cost of entertainment, especially rent and operational cost, increases simultaneously with economic development (Interviewee 11).

\subsubsection{Marketing}

The development of a destination depends on the resources available and demand [42]. Previous researchers have attempted to match supply and demand by connecting tourist motivation and destination choice [43], tourist perceptions and tourist satisfaction [44], and tourism products and the needs of the market segment [45]. The entertainment industry in Macau lacks communication to the local or international media. On the one hand, the lack of internationally recognized local entertainment brands, such as Disney, prevents communication (or promotion) (Interviewee 10). On the other hand, the Macau government does not promote some of the attractions in the old town to tourists (Interviewee 13).

\subsubsection{Management}

The sub-categories of strategic planning, coordination among VIP junket operators, and mass market service are grouped under the theme of management. Unlike the business model in other gaming destinations, such as Las Vegas and Singapore, the gaming industry in Macau is concentrated in VIP business. This business is mainly in the hands of junkets and VIP gambling promoters instead of casino operators. VIP junkets usually possess a network of sub-junkets. Sub-junkets are responsible for enticing VIP clients to gamble, and their main source of income is the commission from the junket operators. Junket operators are responsible for giving loans to these clients and collecting debt afterwards. VIP gambling operators, junkets, or sub-junkets are usually local Chinese groups with in-depth knowledge about a client's credit record. According to Interviewee 8, the credit assessments to high rollers are usually insufficient, which leads to over-lending. An incorrect assessment of credit risk and over-lending increase the operating risks of junkets and VIP gambling operators [46]. Non-gambling business only contributes to less than $10 \%$ of the total revenue (Interviewee 8 ), and no strategic plan exists to balance the revenue between gambling and non-gambling operations; thus, many services, such as translation, are provided in the VIP room only (Interviewee 2).

\subsubsection{Infrastructure}

The fifth problem of entertainment development in Macau is the insufficient capacity of its public entertainment activities. The sub-themes include land scarcity, traffic congestion, accommodations, and physical environment. Macau is a small city and does not have a large carrying capacity for tourists. Moreover, there are too many people and vehicles in the main attractions which create congestion (Interviewee 4). In addition, three- or four-star hotels are insufficient in Macau resulting in high accommodation expenses for visitors (Interviewee 4). Many outdoor projects greatly depend on the weather conditions (Interviewee 1).

\subsubsection{Government Attitudes}

Many interviewees said that government support is necessary to develop entertainment tourism. Similar to other entertainment destinations, the Macau government should support and promote Macau as an entertainment capital (Interviewee 6), encourage new investment in entertainment products, and encourage community innovation. For example, new street shows should be innovated (Interviewee 7). 


\subsubsection{Facilities and Attractions}

Although Macau has many luxurious and fancy casino hotels, restaurants, spas, and shopping centers, another major constraint to entertainment tourism is the lack of world-class natural attractions and facilities to support Macau in developing into an entertainment destination. Furthermore, the process of redevelopment of the old town is too slow. Thus, the attractiveness to both domestic and international tourists is low (Interviewee 2).

\subsubsection{Expertise and Manpower}

Given the fact that Macau has a small population and the government's lack of support to cultivate industry talents, the number of local talents and experts in the entertainment industry is insufficient to support its development. Therefore, Macau cannot develop its own entertainment producers or performers (Interviewee 11).

\section{Discussion and Implications}

Eight major barriers for entertainment tourism development in Macau were identified. This study is important to many key players in the entertainment industry in Macau and other gaming destinations. This section provides a general discussion of our findings and offers several suggestions to overcome these barriers.

\section{$>$ Policies and regulations}

Like any other tourism destination development, government policies and regulations play an important role in determining Macau's entertainment industry and even tourism industry. As Macau is a special administrative region of China, the support from the Chinese government is important to the development of the industry. Statistics reveal that the tourism industry in Macau relies on tourists from China [47]. The most important factor is the entry restriction [48]. For example, residents from Guangdong Province, which is adjacent to Macau, can visit Macau six times per year at a maximum. At the macro-level, the regulation, if it continues to be in force in the future, will be a major barrier for entertainment tourism development. Our finding is consistent with Hsu and Gu's study.

The Macau government may need to seek support from the Mainland Chinese government to further relax this restriction. In addition, the Macau government should also provide additional convenience processes to tourists and residents from the Greater Bay Area (i.e., seven cities in the Pearl River Delta in Guangdong Province plus Hong Kong and Macau) and the Belt and Road Initiative, such as a $24 \mathrm{~h}$ border-crossing policy. "Belt and Road" refers to the land-based "Silk Road Economic Belt" and the seafaring "21st Century Maritime Silk Road". The routes cover countries across Asia, Europe, and Africa. These policies would attract more tourists to visit Macau. At the industry level, as the current license application procedures for the entertainment industry are complicated and time consuming, new policies and regulations are needed to encourage investments and support industry development by simplifying and accelerating the business start-up process [49].

\section{$>$ Cost}

The costs of operation in Macau are high. Among them, rent is considered to be the biggest problem of business in Macau [46]. In addition to rent, a new entertainment company needs equipment, air conditioners, furniture, and so on. These infrastructure elements must be purchased and set up before opening. The Macau government could encourage local banks or set up a new financial institution to provide short- to medium-term loan to facilitate liquidity needs. This would encourage not only more business development but also more diversification [50]. The high cost of production inevitably leads to the fact that many entertainment providers focus on producing relatively high-end products, such as luxury shopping malls and hotels, to overcome this high cost of operation. High tourism expenses are very likely to be a barrier if Macau is to develop into an international entertainment city. To appeal to a wider international range of visitors, the government may consider diversifying its entertainment 
products. However, the efforts to diversify products to cater to different customer sectors within the entertainment industry are far from satisfactory [1]. Instead of focusing on high-end entertainment products, government and entertainment providers should provide free or low-cost entertainment products to the mass market. These free or low-cost products can be in various forms, such as parades and street shows, which can provide entertainment products to residents and tourists.

\section{$>$ Marketing}

Our findings reveal that the marketing effort from the government is very limited. A marketing strategy with a clear brand positioning is also lacking. One marketing strategy is positioning Macau as the "Entertainment Capital" of the world. Furthermore, entertainment providers should develop their "signature" entertainment products with Macau characteristics. For example, the Cirque du Soleil's "O" from the Bellagio in Las Vegas is considered one of the "must-see" shows for tourists. The above-mentioned entertainment products will encourage not only tourists but also local residents to participate. Such initiative also coincides with the "expanding domestic demand" national policy of China.

\section{$>$ Management}

A strong corporate governance is needed for the gambling operator, especially for the junket and sub-junket, and there should be a clear strategic plan. For example, junkets in Singapore are regulated. In addition, many responsible gambling programs are developed to protect vulnerable citizens. Similarly, junkets in South Korea are required by the government to set up a tangible shop to lend gambling chips to the customers. Given that many junkets are reluctant to do so, this requirement reduces the probability of people sidestepping China's limits on taking money away from the country. Sustainable development requires well-designed rules, and responsible gambling is an ethical and sustainable way [39]. Meanwhile, the management team should improve the service level to the mass tourists in Macau.

\section{$>$ Infrastructure}

Land scarcity, traffic congestion, and lack of middle-end accommodation facilities are found to be constraints for further entertainment development. These physical constraints are common in tourism development. Possible remedies are investments in the development and redevelopment of infrastructure. Many infrastructure elements in Macau have been improving [30,31]. For example, on the one hand, visitors will be encouraged to visit Macau due to the opening of the Hong Kong-Zhuhai-Macao bridge. The development of high-speed rails between Macau and Guangdong is expected to have the same effect. On the other hand, Macau is developing its light rail system, which connects hotels, resorts, and other public facilities. Once the rails are established, hospitality capacity will be improved. In addition, bad weather affects entertainment tourism more significantly than other types of tourism. Especially in the case of entertainment tourism with outdoor activities, bad weather reduces people's desire to travel [51]. Therefore, the government should improve Macau's infrastructure, such as plazas, parks, etc.. Infrastructure should be designed which allows people to enjoy the events even under bad weather conditions.

\section{$>$ Government attitudes}

Local and national governments can support entertainment tourism in many ways. The local hospitality capacity problem can be resolved by direct investment in infrastructure elements and in superstructures. The government should encourage the local community to develop new entertainment products. This initiative will also help develop entertainment products with Macau characteristics. Therefore, more government support is needed for tourism development [27]. 


\section{$>$ Facilities and attractions}

Our findings show that the facilities and attractions are neither sufficient nor attractive to appeal to both domestic and international tourists. However, the government is spending much effort to overcome this barrier. For example, Hengqin Island in Macau contains many world-class non-gaming infrastructure elements. The Island has created several policies which are coordinated with the development of Macau [52]. The focus for Hengqin Island is currently on tourism and leisure, logistics and commercial trade, science, education, $R \& D$, cultural creation, high-tech, medicine and healthcare, and financial services [4]. The non-gaming elements in Hengqin, combined with the gaming and entertainment elements in Macau, will attract many different tourists.

\section{$>$ Manpower}

Labor shortage, especially specialists and experts, was found to be a major problem of the entertainment industry in Macau, particularly the gaming industry. This shortage became increasingly severe after six casino operators launched their Cotai properties [46]. Therefore, many gambling operators are spending much effort to retain talents. For example, Sands China increased the basic monthly salary by $5 \%$ and provided 14th month salary in 2014. Furthermore, smoking is completely banned in casinos and employee benefits are improved to provide a better working environment than before [53]. Other casinos use reasonable and clear career paths to retain and attract talents. New rules are expected to be implemented in Macau to attract an increasing number of talents and valued labors from all over the world to support further development.

\section{Conclusions and Limitations}

This study identifies eight barriers for the sustainable development of entertainment tourism in Macau. The results show that policies and regulations, economy, marketing, management, government attitude, expertise and manpower, facilities and attractions as well as infrastructure problems are the main barriers for the development of entertainment tourism in Macau. Our findings are generally congruent with prior tourism studies while adding new insights into the entertainment tourism literature.

We propose several measures that can be taken to promote the development of Macau's entertainment tourism and suggest ways to overcome the barriers for that development. To achieve success in the fiercely competitive entertainment tourism industry, different stakeholders should work together and even form a formal institution to pursue a common long-term strategic goal: to develop Macau into a world-class entertainment tourism destination. Government support for relaxing tourist visit restrictions, improving fundamental and tourism infrastructures, simplifying company start-up procedures, enhancing marketing for a better destination branding, and cultivating or introducing industry talents and experts are indispensable for a better and sustainable development of entertainment tourism. These insights may be also important for other entertainment tourism destinations.

Some limitations of this study should be addressed. The first limitation is the small sample size. Given that many of the senior and general managers and entertainment executives have a tight schedule, inviting a large pool of them was difficult. The busy schedule also limited the amount of time interviewees could express their views on the issue. Future studies can incorporate data from other entertainment destinations. Entertainment tourism development across destinations can also be compared to understand entertainment tourism development in general. Second, due to the limited scope of our study, we only focused on perspectives from the industry, whereas those from the government, tourists as well as the community must be investigated in future research. Insights from different stakeholders will undoubtedly benefit the future sustainable development of entertainment tourism. 
Author Contributions: J.M.L. led the outline of the study. J.M.L. and C.F.L. designed and completed the paper. B.H.Y. reviewed and conducted data analysis of the manuscript.

Funding: This project was partly supported by a research grant funded by the Macau Foundation (MF1826).

Conflicts of Interest: The authors declare no conflict of interest.

\section{References}

1. Luo, J.M.; Lam, C.F. Entertainment Tourism; Routledge: Abingdon, UK, 2017.

2. McCarthy, J. Entertainment-LED Regeneration: The Case of Detroit. Cities 2002, 19, 105-111. [CrossRef]

3. Luo, J.M.; Lam, C.F.; Li, X.; Shen, H. Corporate Social Responsibility in Macau Gambling Industry. J. Qual. Assur. Hosp. Tour. 2016, 17, 237-256.

4. Luo, J.M. A Measurement Scale of Corporate Social Responsibility in Gambling Industry from Customer Perspective. J. Qual. Assur. Hosp. Tour. 2018, 19, 461-476.

5. Blanke, J.; Chiesa, T. The Travel E Tourism Competitiveness Report 2013; World Economic Forum: Geneva, Switzerland, 2013. Available online: http://www3.weforum.org/docs/WEF_TT_Competitiveness_Report_ 2013.pdf (accessed on 1 July 2017).

6. Cohen, M. Macau needs decades to go beyond gambling. Asia Time Online, 30 June 2011. Available online: http:/ / www.atimes.com/atimes/Southeast_Asia/MF30Ae02.html (accessed on 1 June 2018).

7. UNWTO. UNWTO World Tourism Barometer. 2018. Available online: https://www.e-unwto.org/doi/pdf/ 10.18111/wtobarometereng.2019.17.1.1 (accessed on 2 February 2019).

8. PwC. Global Entertainment \& Media Outlook 2018-2022. 2019. Available online: https://www.pwc.com/ $\mathrm{gx} / \mathrm{en} /$ industries/tmt/media/outlook.html (accessed on 2 February 2019).

9. Minton, E. For your amusement: What the entertainment industry is doing for places large and small. Planning 1998, 64, 12-15.

10. "Utopia, Missouri" (1994, December 24). The Economist 1994, 333, $25-29$.

11. Besciu, I.G. Behvior of the consumer of tourist entertainment services. Cactus Tour. J. 2013, 4, 9-19.

12. Hughes, H.; Benn, D. Tourism and cultural policy: The case of seaside entertainment in Britain. Eur. J. Cult. Policy 1997, 3, 235-255. [CrossRef]

13. Adeboye, C.A. The Impact of Enterainmnet on Tourism. Case Study: Agency Remarc in Greece; Central Ostrobothnia University of Applied: Kokkola, Finland, 2012. Available online: https://www.theseus. fi/bitstream/handle/10024/47217/Adeboye_Christopher.pdf?sequence=1 (accessed on 2 February 2018).

14. Vogel, H.L. Entertainment Industry Economics: A Guide for Financial Analysis; Cambridge University Press: Cambridge, UK, 2014.

15. Hughes, H. Arts, Entertainment and Tourism; Butterworth Heinemann: Oxford, UK, 2000.

16. Xu, J.B. Perception of tourism products. Tour. Manag. 2010, 31, 607-610.

17. Loi, K.I.; Pearce, P.L. Powerful stakeholders' views of entertainment in Macao's future. J. Bus. Res. 2012, 65, 4-12. [CrossRef]

18. Suh, E.; West, J.J. Estimating the impact of entertainment on the restaurant revenues of a Las Vegas hotel casino: An exploratory study. Int. J. Hosp. Manag. 2010, 29, 570-575. [CrossRef]

19. Benston, L. Park Place Betting on Dion Success. 2003. Available online: http://m.lasvegassun.com/news/ 2003/mar/21/park-place-betting-on-dion-success / (accessed on 3 February 2019).

20. Luo, J.M.; Lam, C.F.; Fan, D.X. The development of measurement scale for entertainment tourism experience: A case study in Macau. Curr. Issues Tour. 2018, 1-15. [CrossRef]

21. Hatipoglu, B.; Alvarez, M.D.; Ertuna, B. Barriers to stakeholder involvement in the planning of sustainable tourism: The case of the Thrace region in Turkey. J. Clean. Prod. 2016, 111, 306-317. [CrossRef]

22. Formica, S.; Uysal, M. Destination attractiveness based on supply and demand evaluations: An analytical framework. J. Travel Res. 2006, 44, 418-430. [CrossRef]

23. Keyser, H. Tourism Development; Oxford University Press: Cape Town, South Africa, 2002; Volume 374.

24. Sharma, K.K. Tourism and Socio-Cultural Development; Sarup \& Sons: New Delhi, India, 2004.

25. Kay, P.L.; Wong, E.; Polonsky, M.J. Marketing cultural attractions: Understanding non-attendance and visitation barriers. Mark. Intell. Plan. 2009, 27, 833-854. [CrossRef] 
26. Marzo-Navarro, M.; Pedraja-Iglesias, M. Wine tourism development from the perspective of the potential tourist in Spain. Int. J. Contemp. Hosp. Manag. 2009, 21, 816-835. [CrossRef]

27. Heung, V.C.; Kucukusta, D.; Song, H. Medical tourism development in Hong Kong: An assessment of the barriers. Tour. Manag. 2011, 32, 995-1005. [CrossRef]

28. Rokni, L.; Turgay, A.V.; Park, S.H. Barriers of developing medical tourism in a destination: A case of South Korea. Iran. J. Public Health 2017, 46, 930-937. [PubMed]

29. Momeni, K.; Janati, A.; Imani, A.; Khodayari-Zarnaq, R. Barriers to the development of medical tourism in East Azerbaijan province, Iran: A qualitative study. Tour. Manag. 2018, 69, 307-316. [CrossRef]

30. Hsu, C.H.; Gu, Z. Ride on the gaming boom: How can Hong Kong, Macau and Zhuhai join hands to develop tourism in the region? Asia Pac. J. Tour. Res. 2010, 15, 57-77. [CrossRef]

31. Greenwood, V.A.; Dwyer, L. Reinventing Macau tourism: Gambling on creativity? Curr. Issues Tour. 2017, 20, 580-602. [CrossRef]

32. Balsas, C.J. Gaming anyone? A comparative study of recent urban development trends in Las Vegas and Macau. Cities 2013, 31, 298-307. [CrossRef]

33. Macauhub.com. Macao Tourism Growing Stronger. April 2013. Available online: https://macauhub.com. mo/feature/macao-tourism-growing-stronger/ (accessed on 10 March 2019).

34. Inskeep, E. Tourism planning: An emerging specialization. J. Am. Plan. Assoc. 1988, 54, 360-372. [CrossRef]

35. Strauss, A.; Corbin, J. Basics of Qualitative Research: Procedures and Techniques for Developing Grounded Theory; Sage: Thousand Oaks, CA, USA, 1998.

36. Macao Government Tourism Office (MGTO). Shows \& Entertainment. 2019. Available online: http://en. macaotourism.gov.mo/showentertainment/showentertainment.php?c=1 (accessed on 10 March 2019).

37. Glaser, B.; Strauss, A. The Discovery of Grounded Theory: Strategies for Qualitative Research; Routledge: New York, NY, USA, 2017.

38. Mabuza, L.H.; Govender, I.; Ogunbanjo, G.A.; Mash, B. African Primary Care Research: Qualitative data analysis and writing results. Afr. J. Prim. Health Care Fam. Med. 2014, 6, 1-5. [CrossRef]

39. Jennings, G. Tourism Research; John Wiley \& Sons Australia Ltd.: Milton, Australia, 2011.

40. Sheng, L. Foreign investment and urban development: A perspective from tourist cities. Habitat Int. 2011, 35, 111-117. [CrossRef]

41. Gaming Inspection and Coordination Bureau (DICJ). Information, 2019. Available online: http://www.dicj. gov.mo/web/en/information/index.html (accessed on 10 March 2019).

42. Hu, Y.; Ritchie, J.B. Measuring destination attractiveness: A contextual approach. J. Travel Res. 1993, 32, 25-34.

43. Andreu, L.; Kozak, M.; Avci, N.; Cifter, N. Market segmentation by motivations to travel: British tourists visiting Turkey. J. Travel Tour. Mark. 2006, 19, 1-14. [CrossRef]

44. Kandampully, J. The impact of demand fluctuation on the quality of service: A tourism industry example. Manag. Serv. Qual. Int. J. 2000, 10, 10-19. [CrossRef]

45. Lubbe, B.A.; Douglas, A.; Fairer-Wessels, F.; Kruger, E.; Geldenhuys, E.; Francis, C. Matching Tourism Supply and Demand: An analysis of how tourism products meet the needs of emerging domestic market segments in selected regions in South Africa. In Tourism Travel and Research Association: Advancing Tourism Research Globally; Travel and Tourism Research Association: Whitehall, MI, USA, 2016; p. 25. Available online: http:/ / scholarworks.umass.edu/ttra/2013/AcademicPapers_Oral/25 (accessed on 1 September 2019).

46. Leitao, L. The Casino City Where Staff Keep Disappearing. 2016. Available online: https://www.bbc.com/ news/business-35351416 (accessed on 5 March 2019).

47. Macao Statistics and Census Bureau (DSEC). Tourism and Gaming. 2019. Available online: http:/ / www. dsec.gov.mo/default.aspx\# (accessed on 1 March 2019).

48. Sheng, M.; Gu, C. Economic growth and development in Macau (1999-2016): The role of the booming gaming industry. Cities 2018, 75, 72-80. [CrossRef]

49. Macau Times. News, 2017. Available online: http://www.jornalsisi.com/news-cd.asp?id=23567 (accessed on 1 March 2019).

50. Whitfield, R. Macau Matters. 2017. Available online: https://macaudailytimes.com.mo/macau-mattersanother-way-supporting-new-small-medium-enterprises.html (accessed on 1 March 2019).

51. Luo, J.M.; Lam, C.F.; Qiu, H.; Fan, D.X. The Impact of Climate on Outbound Tourism in Hong Kong: Resident's Mode of Transport. J. Manag. Sustain. 2015, 5, 31-40. [CrossRef] 
52. O'Neill, M. Pushing the Frontier-Macao Seeks Extra Land on Fast-Growing Hengqin Island. 2014. Available online: https:/ / macauhub.com.mo/feature/pushing-the-frontier-macao-seeks-extra-land-on-fast-growinghengqin-island/ (accessed on 1 December 2018).

53. Luo, J.M.; Lam, C.F. Corporate Social Responsibility and Responsible Gambling in Gaming Destination; Nova Science Publishers: New York, NY, USA, 2016. 